JINOTEP Vol 8 (3) (2021): 237-246

DOI: $10.17977 / \mathrm{um} 031 \mathrm{v} 8 \mathrm{i} 32021 \mathrm{p} 237$

JINOTEP (Jurnal Inovasi Teknologi Pembelajaran)

Kajian dan Riset Dalam Teknologi Pembelajaran

http://journal2.um.ac.id/index.php/jinotep/index

\title{
EFEKTIVITAS DEVOTION SEBAGAI METODE PELATIHAN PENINGKATAN ETOS KERJA GENERASI MILLENIAL
}

\author{
I Putu Dharmawan Pradhana, Hose Hongcapryo Nando, Kadek Adyatna Wedananta \\ Universitas Pendidikan Nasional
}

\section{Article History \\ Received: 20-03-2021}

Accepted: 24-09-2021

Published: 01-11-2021

\section{Keywords}

Disruption Era;

Devotion; Character

Building Training; Work

Ethic.

\begin{abstract}
Abstrak
Program pelatihan pembentukan karakter oleh BSA yaitu Devotion yang dilakukan setiap hari sebelum memulai kegiatan belajar mengajar diyakini sangat efektif dalam membentuk karakter siswa-siswi BSA. Hal ini diperlukan mengingat revolusi industri 4.0 memicu terjadinya perkembangan teknologi yang sangat pesat dan munculnya era disrupsi yang merubah sistem lama dengan cara-cara baru yang lebih efektif dan efisien. Penelitian ini bertujuan untuk mencari efektivitas Devotion sebagai pelatihan pembentukan karakter dalam membentuk etos kerja siswa-siswi generasi millenial untuk siap terjun di dunia pekerjaan dalam era disrupsi. Penelitian bersifat kualitatif dengan metode pengumpulan data yang digunakan adalah teknik wawancara dan observasi dari beberapa informan. Penelitian ini menyimpulkan bahwa Devotion sangat efektif dalam menciptakan lulusan yang memiliki etos kerja yang cukup baik dan mampu mengikuti dan menyikapi setiap perubahan tanpa mengabaikan aspek spiritual dan berbudi pekerti yang luhur.
\end{abstract}

\begin{abstract}
The character development training program by BSA, namely Devotion which is carried out every day before starting teaching and learning activities is believed to be very effective in shaping the character of BSA students. This is necessary considering that the industrial revolution 4.0 has triggered a very rapid technological development and the emergence of an era of disruption that changed the old system with new, more effective and efficient. The purpose of this study is to see the effectiveness of Devotion as character development training at the Bali Star Academy to form the work ethic of millennial generation students to be ready to enter the workforce in the era of disruption, qualitative research with data collection methods used is interview and observation techniques from several informants. This study concludes that Devotion is very effective in creating graduates who have a fairly good work ethic and they are able to follow and respond to any changes without neglecting the spiritual aspects and noble character.
\end{abstract}

Corresponding author:

Adress: J1. Cenigansari IV No 17 Sesetan,

Denpasar Selatan, Kota Denpasar, Bali, 80223

Instansi: Universitas Pendidikan Nasional,

E-mail: pradhana@undiknas.ac.id
2021 Universitas Negeri Malang p-ISSN 2406-8780 e-ISSN 2654-7953 


\section{PENDAHULUAN}

Revolusi Industri 4.0 memberikan inovasiinovasi teknologi yang memicu terjadinya disrupsi dalam berbagai bidang yang memberikan berbagai tantangan dan peluang. Revolusi Industri 4.0 dengan Penelitian Tantangan Globalisasi tidak hanya untuk berdampak di bidang teknologi, tetapi sudah mendisrupsi dalam bidang sosial, hukum, dan ekonomi. Akibat yang ditimbulkan dari disrupsi ini membuat tatanan dunia berubah drastis (Prasetyo \& Trisnayanti., 2018). Era disrupsi adalah fenomena yang awalnya dari dunia nyata ke dunia maya ketika masyarakat menggeser aktivitas-aktivitas yang awalnya di dunia nyata. Disrupsi adalah perubahan berbagai sektor akibat digitalisasi dan "Internet of Things" atau "Internet for Everyone," perubahan yang tidak terduga menjadi fenomena yang akan sering muncul di era revolusi industri 4.0. Perkembangan teknologi digital telah membuat beberapa aspek kehidupan manusia. Internet seolah menjadi bagian vital dalam berbagai aktivitas masyarakat. Dengan adanya perkembangan yang sangat signifikan dalam dunia digital, turut mengubah karakteristik dari masyarakat maupun individu dengan sangat cepat. Perkembangan aneka teknologi mutakhir ini tidak saling berdiri sendiri tetapi saling terjalin dan terintegrasi satu sama lain sehingga secara fundamental mengubah cara kerja manusia. Lebih dari itu teknologi super canggih ini tidak hanya tertanam dalam kehidupan dan cara kerja masyarakat tetapi, juga tertanam dalam tubuh manusia. Batas-batas antara manusia dan teknologi seolah melebur (Wijanarko, 2019).

Berkembangnya zaman menuntut setiap orang dalam menghadapi revolusi Industri 4.0 harus siap menyesuaikan diri dan melakukan inovasi untuk menghadapi era disrupsi. Berbagai hal yang dirasa tidak efektif pada setiap aktivitas kehidupan akan tergantikan dengan pola baru yang lebih praktis dengan sentuhan teknologi. Perubahan yang sangat signifikan ini menjadi tantangan bagi Sebagian besar masyarakat untuk dapat tetap eksis dengan menerima setiap perubahan yang ada. Ghufron (2018) menyatakan bahwa Revolusi Industri 4.0 merupakan suatu revolusi teknologi yang dapat mengubah berbagai pola aktivitas manusia dari kehidupan sebelumnya dimana terdapat perubahan dalam skala, ruang lingkup, transformasi dan kompleksitasnya. Manusia bahkan diharuskan untuk dapat menjalankan kehidupan di dalam suatu ketidakpastian. Kemampuan untuk memprediksi masa depan yang sangat dinamis juga sangat diperlukan.

Perubahan etos kerja juga menjadi problematika tersendiri yang terkadang menimbulkan konflik tertentu baik secara vertikal maupun horizontal. Etos kerja berkaitan dengan persoalan "gimana kamu berlagak serta apa yang kalian jalani?" "Gimana kamu berlagak" memperagakan sikap konkret yang yang mengekspresikan nilai- nilai moral tersebut (etika). Etos mewujudkan tafsiran dan terjemahan nilai-nilai moral (etika) itu menjadi Tindakan nyata (Desmon, 2016). Etos Kerja yang dipunyai seorang sangat berguna buat menggerakan atau pun mendesak kinerja yang baik. Oleh sebab itu, besar rendahnya etos kerja sesuatu warga, sangat bergantung pada bagaimana metode memandang permasalahan dasar dalam kehidupan manusia. Perihal ini bisa tingkatan besar atau pun rendahnya etos kerja warga yang bersangkutan serta pula bisa berperan buat memunculkan semangat dalam bekerja.

Sebagai salah salah satu alternatif dalam mengembangkan etos kerja, pelatihan dan pengembangan karakter sangat dibutuhkan. Pengembangan karakter tidak dapat dilepaskan dari pengembangan kompetensi teknis yang dimiliki. Dengan adanya perpaduan antara kepribadian yang luhur dan kemampuan teknis yang mumpuni, maka akan tercipta harmonisasi dalam bekerja dan keselarasan etos kerja sehingga dapat meminimalisir konflik antar generasi. Menurut Mathis (2002), Pelatihan adalah sebuah proses dimana orang-orang menggapai keahlian tersebut untuk menolong mencapai tujuan organisasi. Oleh karena itu pelatihan yang baik dan tepat sejak bangku 
pendidikan sangatlah penting untuk mempersiapkan sumber daya manusia dalam menghadapi segala jenis tantangan dan perubahan di era disrupsi. Pembentukan karakter yang positif diharapkan dapat memberi motivasi dan kepercayaan diri setiap individu untuk menghasilkan kinerja yang baik dan tidak gentar dalam menghadapi berbagai perubahan.

Dalam memanfaatkan berbagai peluang pada era revolusi industri 4.0, para pemangku kepentingan memiliki kewajiban untuk menguasai literasi data, teknologi dan sumber daya manusia. Literasi data dibutuhkan bagi individu untuk dapat mengolah dan menganalisis big data untuk meningkatkan berbagai layanan khususnya yang terkait dengan customer dan publik. Literasi teknologi sangat diperlukan dalam berbagai pemanfaatan teknologi digital. Tentunya Literasi sumber daya manusia sebagai penyempurna dimana elemen soft skill atau pengembangan karakter individu sangat dibutuhkan untuk bisa berkolaborasi, adaptif dan menjadi arif di era "banjir" informasi (Risdianto, 2019).

Dunia Pendidikan tidak dapat luput dari perubahan untuk dapat memegang peranan penting dalam setiap perubahan itu sendiri. Pendidikan merupakan suatu proses mempersiapkan peserta didik untuk bisa hidup terhormat dan bermartabat di masa depan, dan hal ini dirasa penting. Perubahan yang lebih pesat menyebabkan masa depan tidak dapat diprediksi secara akurat. Hal ini tentu saja menyulitkan dunia Pendidikan untuk dapat meningkatkan peranan dan tugasnya dengan baik dan benar. Dengan berbagai keterbatasan, dunia Pendidikan diwajibkan untuk mempersiapkan suatu sistem yang dapat meningkatkan relevansi bagi peserta didik yang akan menjalankan kehidupan di masa yang akan datang dan bagaimana peserta didik harus bersikap di masa sekarang. Menggagas masa depan masyarakat dan masa depan pendidikan adalah keperluan pokok (Maemunah, 2018). Pendidikan merupakan modal bagi manusia dalam mempertahankan peradaban. Pendidikan yang telah membantu manusia mencapai kesuksesan. Proses pendidikan sudah terjadi sejak lama, berbagai cara telah diciptakan agar perolehan ilmu lebih mudah dan efisien (Lubis,
2019). Di saat teknologi dan media digital semakin berkembang dalam masyarakat kontemporer, hubungan antara pendidikan dan 'digital' terus menjadi perhatian khusus bagi para akademisi. Teknologi digital saat ini bagian yang tidak dapat dipisahkan dari dunia Pendidikan. Hal ini tidak terbayangkan bahkan beberapa tahun yang lalu dimana para pelajar dan pendidik memiliki akses informasi yang belum pernah ada sebelumnya dan komunikasi dapat dilakukan melalui berbagai perangkat digital portabel dan personal (Selwyn, 2013).

Namun dilihat dari fakta yang banyak ditemukan, masyarakat harapan kepada lembaga sekolah tidak ada, dimana berbagai peristiwa yang merusak moral siswa disebabkan oleh buruknya system pembelajaran dan rendahnya budaya moral di sekolah tidak ada (Hamzah, 2016). Hal ini tentu saja harus disikapi dengan serius, mengingat Lembaga Pendidikan sangat besar perananannya dalam membentuk karakter generasi muda harapan bangsa.

Salah satu Lembaga Pendidikan yang berupaya untuk menciptakan sumber daya manusia yang tetap memiliki karakter positif di masa depan adalah Bali Star Academy yang berdiri sejak tahun 2006 dan bernaung di bawah Yayasan Berkat Bagi Bali (Gereja Morning Star Indonesia). Lembaga Pendidikan ini didirikan oleh Ps. DR. Dedy Ndun, M.Th, CBC. Devotion merupakan program pelatihan pembentukan karakter di Bali Star Academy (BSA). Devotion adalah kegiatan yang wajib diikuti oleh seluruh murid, guru, karyawan bahkan orang tua murid di BSA. Devotion lebih menerapkan pembentukan karakter berbentuk seminar dengan pemateri yang memaparkan berbagai hal seputar pengembangan karakter. Adapun materi yang di angkat diambil dari kurikulum Character First Education dengan 29 karakter yaitu: Attentiveness, Availability, Compassion, Conservation, Courage, Creativity, Dependability, Determination, Diligence, Discretion, Enthusiasm, Flexibility, Forgiveness, Generosity, Gratefulness, Honesty, Initiative, Loyalty, Obedience, Orderliness, Patience, Punctuality, Respect, Responsibility, Self-control, Sensitivity, Thoroughness, Tolerance, dan Wisdom. 
240 JINOTEP (Jurnal Inovasi dan Teknologi Pembelajaran) Kajian dan Riset dalam Teknologi Pembelajaran Vol.8, No.3, November 2021, Hal. 237-246

Namun belum terujinya efektivitas Devotion inilah yang menyebabkan pertanyaan. Hal ini disebabkan karena aktivitas Devotion yang dilaksanakan setiap hari sebelum memulai aktivitas, dinilai dapat menyita waktu yang dianggap efektif untuk proses belajar mengajar secara formal dan juga menambah jam kerja bagi karyawan BSA. Hal ini diperburuk dengan minimnya informasi terkait dengan kualitas SDM dan kinerja dari lulusan BSA. Tentunya berbagai pelatihan dan pengembangan etos kerja karyawan yang diadakan secara rutin oleh berbagai perusahaan sangat dibutuhkan khususnya bagi perusahaan yang memiliki karyawan dengan lulusan fresh graduated yang masih tergolong millennial. Pada era disrupsi dimana beberapa kalangan masih belum siap dengan perkembangan yang sangat pesat namun memiliki konektivitas yang kuat kepada kalangan milenial pada suatu perusahaan atau organisasi, dirasa sangat rentan terhadap berbagai benturan di dalam setiap interaksi antar karyawan. Hal inilah yang menjadi dasar bagi penulis untuk dapat mengkaji lebih dalam terkait dengan konsep pelatihan 'Devotion' dan efektifitasnya dalam menciptakan karakter yang tidak hanya cerdas, namun memiliki budi pekerti yang luhur dan tetap mengikuti setiap perkembangan yang ada di era disrupsi. Hal ini sangat penting mengingat metode dari devotion memiliki karakteristik tersendiri yang tentunya perlu pendalaman terkait dampak dari Devotion terhadap para pekerja. Hal ini dilandasi pemikiran bahwa desain program pelatihan memiliki dampak paling kuat pada kinerja pekerjaan pasca pelatihan, bersama dengan kemanjuran diri dan perilaku pasca pelatihan. (Diamantidis \& Chatzoglou, 2014)

Devotion berupaya mengembangkan karakter positif tanpa mengabaikan keterampilan sebagai salah satu aspek penting. Setiap peserta didik harus membekali diri dengan pengetahuan yang kuat tentang regulasi, kompetensi, dan keterampilan untuk mengembangkan keterampilan dan pola pikir menghadapi tantangan di era disrupsi ini (Syakdiyah et al., 2019). Hal ini sangat terkait dengan karakteristik dari generasi $\mathrm{Y}$ atau yang kerap kali disebut dengan generasi Milenial.
Generasi ini lahir kurang lebih tahun 1980 hingga 2000. Jadi dapat dikatakan generasi milenial merupakan generasi muda masa sekarang yang disaat ini berumur dekat 15-34 tahun. Kisaran umur tersebut cocok dengan ratarata umur mahasiswa yang lagi menempuh pembelajaran di perguruan tinggi antara 19-34 tahun (Hidayatullah et al., 2018). Genus Y merupakan generasi online, yang memiliki karakter bergerak dengan cepat, sering tidak sabar, kreatif, dan menuntut dibandingkan dengan generasi lainnya. Kolaborasi dan kerjasama dibutuhkan antara karyawan dari berbagai generasi untuk memberikan layanan yang baik dalam pekerjaannya. Berdasarkan fenomena ini, sebuah organisasi atau bisnis harus mempertimbangkan jumlah hari yang dihabiskan seseorang di tempat kerja tertentu untuk mencapai tingkat etos dan keterikatan kerja yang tinggi untuk bisnis yang sukses (Adi \& Indrawati, 2019). Jessica Brack (LaCore, 2015) menyatakan bahwa generasi milenial memiliki rasa optimis terhadap penghasilan yang diperoleh dan masa depan mereka tetapi mereka sangat rentan terhadap permasalahan terkait dengan tingkat kemampuan kerja yang mereka miliki. Mereka juga menaruh perhatian khusus terhadap pelatihan dan keterampilan kerja yang dibutuhkan untuk bersaing dalam jangka panjang. Milenial dan pasca-milenial membawa serta karakteristik yang berbeda dan ciri-ciri perilaku yang akan memperkenalkan dinamika baru dalam pengaturan organisasi. Karena itu, organisasi harus hati-hati mendiagnosa dampak dari isu-isu yang dibawa oleh generasi baru memasuki angkatan kerja dan merancang intervensi yang tepat untuk memastikan bahwa organisasi tetap efektif, efisien dan terus berkinerja dengan sukses (Otieno \& Nyambegera, 2019).

Campione (2015) mengungkapkan bahwa tahap awal dalam menangani perilaku generasi milenial adalah memahami nilai, sikap, dan sifat kepribadian mereka yang berhubungan dengan pekerjaan dan bagaimana hal ini mempengaruhi kemampuan mereka untuk mempelajari tugas pekerjaan, harapan sosial, dan organisasi; bagaimana hal ini mempengaruhi kemampuan beradaptasi mereka untuk menegosiasikan peran 
mereka di tempat kerja; dan bagaimana hal ini mempengaruhi penilaian mereka terhadap rekan kerja dan penyelia mereka Campione (2015)

Generasi milenial dan generasi sebelumnya memiliki ciri khusus dan kinerja sesuai dengan karakteristik dari masing-masing generasi tersebut. Para pelaku bisnis dapat menggunakan perilaku paralel ini untuk dapat meraih keuntungan. Setelah mengidentifikasi orangorang berprestasi tinggi dari generasi sebelum Milenial, para manajer dapat membekali mereka untuk mempersiapkan diri, memberdayakan dan membimbing orang-orang berkinerja tinggi dari Generasi Y dan Z (Darby \& Morrell, 2019)

Adapun hal yang tidak dapat diabaikan adalah soft skill yang dimiliki oleh pekerja milennial dalam mendukung kinerja maksimal. Soft skill memiliki peran dalam menciptakan sumber daya yang tidak hanya memiliki kemampuan dalam bekerja sesuai dengan bidang kerjanya, namun akan membentuk kinerja yang unggul dan berkualitas. Soft skill sangat terkait dengan kepribadian yang dapat menciptakan harmonisasi dalam interaksi personal antar individu, kinerja dan peningkatan karir. Soft skill tidak dapat dinilai dan dilihat secara langsung (Syamsuddin, 2020).

Santoso et al. (2019) menyatakan bahwa soft skill terdiri dari personal, interpersonal maupun kombinasi dari keduanya. Tentu saja hal ini mendukung generasi Milenial untuk menghadapi dunia kerja di era revolusi industri 4.0. Dalam dunia kerja, soft skill sangat penting sejak proses rekrutmen atau seleksi karyawan hingga setelah diterima sebagai karyawan dan mengerjakan tugas. Keseimbangan antara keterampilan dan kepribadian teramat penting. Jika seseorang hanya mengandalkan kemahiran atau hard skill, tentu akan tersisihkan oleh para pekerja yang memiliki tingkat soft skill yang baik. Tentu saja Devotion dapat menjadi harapan bagi pembentukan karakter millennial atau generasi selanjutnya untuk dapat mengikuti berbagai perkembangan namun tetap memiliki softskill sehingga pergesekan atau konflik yang menyertai sesama generasi maupun dengan generasi sebelumnya.

\section{METODE}

Penelitian ini berlokasi di Bali Star Academy yang beralamat di Jl. Raya Bypass Ngurah Rai no. 447, Suwung Batan Kendal, Sesetan, Denpasar, Kota Denpasar Bali. Data kualitatif merupakan jenis data yang digunakan dalam penelitian ini. Penelitian kualitatif dapat digunakan untuk menyelidiki kehidupan masyarakat, sejarah, perilaku, konsep atau fenomena, masalah sosial, dan sebagainya. Hal inilah yang menjadi acuan penulis untuk menggunakan data kualitatif dalam penelitian ini. Penulis ingin mengetahui secara nasional apakah pelaksanaan pengabdian dapat menciptakan etos kerja yang baik bagi generasi milenial di era disrupsi.

Data primer dan sekunder yang digunakan dalam penelitian ini. Data primer adalah data yang diolah dari sumber-sumber asli, yaitu sumber pertama yang dioleh oleh wawancara mendalam dengan mencantumkan hari atau tanggal, waktu, dan tempat pelaksanaan wawancara kepada responden yang sudah ditentukan. Data Sekunder adalah data yang diolah secara tidak langsung dari objek yang bersangkutan, namun melalui orang atau sumber lainnya.

Pemilihan informan pertama merupakan hal yang sangat utama sehingga harus dilakukan secara cermat. Informan yang digunakan dalam penelitian ini dipilih secara purposive, oleh karenanya peneliti memutuskan informan yang paling sesuai yaitu Alumni BSA, Guru BSA, Pemilik BSA dan Orang tua Alumni BSA.

Instrumen penelitian yang digunakan dalam penelitian ini menggunakan Pedoman wawancara yang diharapkan dapat menjadi landasan peneliti dalam memberikan pertanyaan-pertanyaan yang mengandung informasi mengenai objek penelitian, sebelum melaksanakan wawancara maka peneliti menyiapkan beberapa daftar pertanyaan sesuai dengan pokok permasalahan. Selain pedoman wawancara, peneliti juga menggunakan seperangkat alat perekam suara yang dapat menjadi salah satu alat bukti peneliti untuk mendapatkan informasi melalui wawancara dan guna mencegah terlawatinya informasi yang telah diberikan oleh informan terkait. Adapun 
242 JINOTEP (Jurnal Inovasi dan Teknologi Pembelajaran) Kajian dan Riset dalam Teknologi Pembelajaran Vol.8, No.3, November 2021, Hal. 237-246

alat perekam yang digunakan dalam penelitian ini adalah alat komunikasi berupa Handphone.

Miles dan Huberman menyatakan bahwa Analisis data dilakukan dengan mengatur urutan data, mengorganisasikan ke dalam pola, kategori dan satuan uraian dasar, selanjutnya dibandingkan dengan teori-teori yang mendasari penelitian ini untuk selanjutnya ditarik kesimpulan sebagai hasil penelitian. Miles dan Huberman (Sugiyono, 2010) mengemukakan, bahwa aktivitas dalam analisis data kualitatif dilakukan secara interaktif dan berlangsung secara terus-menerus sampai tuntas sehingga data sudah jenuh. Aktivitas dalam analisis yaitu: reduksi data, penyajian data, dan menarik kesimpulan atau verifikasi.

Penelitian ini menggunakan triangulasi sumber, Teknik, dan waktu dalam Teknik pemeriksaan keabsahan data.

Penelitian ini menggunakan data kualitatif deskriptif dengan wawancara mendalam yang berpedoman pada pedoman wawancara serta merekam melalui handphone. Informan penelitian yaitu Alumni BSA, Guru BSA, serta Pemilik BSA. Teknik analisis data menggunakan model interaktif, teknik keabsahan data menggunakan triangulasi yaitu pengecekan dara dari berbagai sumber dengan berbagai cara, dan berbagai waktu (Sugiyono, 2017).

\section{HASIL}

Wawancara dilakukan oleh alumni BSA dan disimpulkan bahwa Para alumni BSA sepakat bahwa Devotion adalah hal penting di hidup mereka dalam membentuk karakter mereka, Devotion membantu mereka dalam mengintropeksi diri dan berperilaku yang benar di dunia pekerjaan maupun organisasi, Devotion yang setiap topiknya selama sebulan diberikan berulang-ulang kali itu membuat mereka menjadi terbiasa dan terbawa hingga sekarang, tidak hanya untuk mendengarkan pelatihan karakter namun secara spiritual juga berdoa kepada Tuhan untuk "self control in daily life". Alumni BSA secara sadar atau pun mereka tidak sadari memiliki rasa kepedulian yang tinggi terhadap sekitarnya dan mampu ber-empati dengan baik, rasa tanggung jawab mereka bisa buktikan dengan benar-benar menyelesaikan pekerjaan dengan efektif dan efisien. Dalam menyikapi era disrupsi mereka memberikan jawaban yang hampir sama, Devotion membentuk karakter mereka untuk dapat mengikuti dan menerima perubahan tersebut sehingga tidak akan mengganggu etos kerja mereka.

Wawancara kedua dilakukan dengan memberikan serangkaian pertanyaan kepada para guru di BSA dan mereka menyebutkan bahwa Devotion sangat penting dan sebagai penunjang yang efektif dalam pembentukan karakter anak-anak di BSA, karena diberikan setiap hari dan akan selalu dibahas kembali di kelas, di sekolah, bahkan juga di lingkungan rumah mereka, dan dibantu juga dengan membuat devotion journal adalah laporan tentang apa yang mereka pelajari dalam Devotion setiap hari yang harus diberikan contoh kasusnya. Dalam pemberian materi tidak pernah ada kendala yang berarti, karena materi yang disampaikan adalah materi yang sudah siap dan kendala yang lebih sering terjadi hanya pada kendala teknis yang sedikit mengganggu namun tidak menghambat pemberian materi pada Devotion itu. Pemberian rewards and punishment juga diberlakukan pada Devotion untuk lebih memaksimalkan penyampaian materi pembentukan karakter ini. Dalam menghadapi era disrupsi pemberian materi Devotion selalu disisipkan tantangan-tantangan yang akan dihadapi setiap hari pada zaman sekarang ini, contoh-contoh yang diberikan adalah hal yang tidak asing dari apa yang akan mereka hadapi di dunia pekerjaan nanti. Salah satu cara pembentukan etos kerja dalam Devotion adalah dengan melibatkan anak-anak BSA sedini mungkin bertanggung jawab pada setiap event di BSA, mulai dari SD hingga SMA semua ikut terlibat dan diberikan tanggung jawab sesuai dengan umur dan porsinya masingmasing, semakin tinggi kelasnya semakin besar tanggung jawab yang diberikan, semua itu dilakukan untuk mereka siap bukan hanya ilmu akademis tapi juga menyiapkan etos kerja yang siap di dunia pekerjaan nanti. Mereka menyatakan jika harus menunggu seseorang lulus SMA dan kemudian baru kuliah dan baru 
bekerja untuk melihat etos kerjanya maka BSA tidak berbeda dari sekolah lain pada umumnya.

Wawancara ketiga dilakukan oleh pemilik BSA dan dapat disimpulkan bahwa Menempatkan Tuhan sebagai yang terutama, filosofi dan tujuan Devotion sebagai put God first, juga kebenarannya bahwa orang yang takut akan Tuhan adalah permulaan hikmat, jadi supaya anak punya hikmat mereka harus belajar respect Tuhan atau takut terhadap Tuhan. Karakter utama yang diharapkan dari Devotion love God, love people.

\section{PEMBAHASAN}

Berdasarkan hasil wawancara dengan beberapa informan terpilih di Bali Star Academy maka untuk mengetahui perbandingan antara teori Kabul Budiyono mengenai tujuan pendidikan karakter, dapat dilihat pada pembahasan sebagai berikut:

Menurut Budiono (2007), Pembelajaran Karakter atau pun Pembelajaran Karakter bertujuan buat menciptakan partisipan didik dengan perilaku serta sikap, adalah; ( 1) Beriman serta bertaqwa kepada Tuhan Yang Maha Esa, (2) Berperikemanusiaan yang adil serta beradab, (3) Menunjang persatuan bangsa, (4) Menunjang kerakyatan yang mengutamakan kepentingan bersama di atas kepentingan orang serta kalangan.

Hal tersebut diatas sejalan dengan penelitian ini, dimana; (1) Beriman dan bertaqwa kepada Tuhan adalah hal utama yang menjadi dasar pembentukan karakter pada BSA dalam Devotion. Maka dapat diThe implication of this study is developing the students' worksheet based on higher order thinking skills for sixthgrade elementary students in order to enhance their critical thinking skills, creative thinking, problem solving and working collaboratively. The teacher could improve the worksheet by adjusting the students' cognitive skills based on the material. Moreover, in developing the worksheet the teacher should determine the blueprint of the worksheet and design an attractive activity for the students. Considering the development of higher order thinking skills worksheets for sixth-grade elementary students is still limited for the teacher, the minister of education might create a program, workshop or internship for the teacher to increase the knowledge related to higher order thinking skills. This activity could escalate the application of higher order thinking skills for the students.
Moreover, the teacher can create a community that focuses on developing higher order thinking materials for elementary studentslihat lulusan BSA selalu mengedepankan Tuhan dalam segala hal yang mereka akan lakukan, (2) Terbiasa dengan lingkungan yang menghormati segala perbedaan membuat mereka mampu untuk menghargai setiap individu dan selalu untuk memberikan kesempatan orang lain untuk berkembang dan menunjukan yang terbaik dari individu tersebut, (3) Mereka memahami betul makna dari persatuan bangsa, mereka percaya bahwa hal hebat tidak dapat dilakukan sendiri namun harus dilakukan bersama-sama, (4) Do it for God and for others, love God and love people. Selalu menempatkan Tuhan dan juga orang lain, karakter yang tumbuh sangat mencerminkan kepentingan bersama lebih penting dari kepentingan individu dan golongan.

Berdasarkan hasil wawancara dengan beberapa informan terpilih di Bali Star Academy maka untuk mengetahui perbandingan antara teori Anoraga mengenai sikap etos kerja, dapat dilihat pada pembahasan sebagai berikut:

Menurut Anoraga Anoraga (2001), sekian banyak perilaku etos kerja, adalah; (1) Kecanduan Terhadap Waktu. Salah satu esensi serta hakikat dari etos kerja yakni kiat seorang menghayati, menguasai, dan pula merasakan betapa berharganya waktu. (2) Mempunyai Moralitas yang Bersih (Ikhlas). Salah satu dari kompetensi moral yang dimiliki oleh seseorang yang berbudaya kerja iyalah nilai keihklasan. (3) Mempunyai Kejujuran. Kejujuran ini tidak tiba dari luar, tetapi tiba dari hati serta pemikiran yang baik. Kejujuran ini tidaklah suatu keterpaksaan, tetapi melainkan kejujuran ini adalah suatu panggilan dari dalam suatu keterikatan. (4) Mempunyai komitmen. Komitmen itu adalah kepercayaan yang mengikat sedemikian kukuhnya sehingga terbelenggu segala hati nuraninya serta sehabis itu menggerakkan sikap mengarah arah tertentu yang diyakininya. (5) Kokoh Pendirian (Tidak berubah-ubah). Tidak berubah- ubah ini pula adalah sesuatu keahlian buat berlagak taat asas, pantang menyerah, dan pula sanggup mempertahankan prinsip walaupun wajib berhadapan dengan efek yang membahayakan dirinya. Mereka bisa mengatur diri dan mengelola emosi secara efisien.

Hal tersebut diatas sejalan dengan penelitian ini, dimana; (1) Kecanduan terhadap waktu disini dapat dilihat ketika alumni dari BSA mempunyai karakter dimana management 
waktu sangatlah penting, menyelesaikan tugas atau pekerjaan secara efektif dan efisien terutama untuk bisa membagi waktu dengan baik. (2) Alumni BSA yang mempunyai karakter bahwa apa yang mereka kerjakan adalah untuk Tuhan dan untuk orang disekitar kita bukan hanya untuk diri kita sendiri, ikhlas dalam bekerja dan memberikan yang terbaik. (3) Alumni BSA mempunyai karakter dimana mereka selalu membuat apa yang mereka lakukan dan hadapi dilakukan untuk Tuhan, kejujuran adalah hal penting yang diajarkan dalam agama dan juga dalam membentuk karakter orang. (4) Komitmen yang dimiliki anak-anak BSA untuk menjadi yang terbaik di hadapan Tuhan dan orang sekitarnya membuat mereka bisa yakin memberikan 100\% kepada apa tanggung jawab yang diberikan kepada mereka. (5) Konsistensi merupakan hal yang dipertahankan dalam Devotion sadar bahwa membentuk karakter orang membutuhkan proses dan pembiasaan setiap pembahasan topik materi yang diberikan akan di ulang dan diberikan selama sebulan penuh, membuat anak-anak BSA terbiasa dengan konsistensi dan mempertahankan apa yang baik.

Berdasarkan hasil wawancara dengan beberapa informan terpilih di Bali Star Academy maka untuk mengetahui perbandingan antara penelitian terdahulu, dapat dilihat pada pembahasan sebagai berikut:

Penelitian Berjudul Analisis Terhadap Pelatihan dan Pengembangan Karyawan bagi Peningkatan Kinerja di PT. Pegadaian Gorontalo Utara (Karuntu et al., 2014) menyatakan bahwa Lewat pelatihan serta pengembangan SDM, manajemen industri pada PT. Pegadaian Gorontalo Utara, mengambil khasiat paling utama dalam melaksanakan perencanaan karir spesialnya pada karyawan dalam jangka panjang, serta buat menolong mengalami tanggung jawab yang lebih besar untuk para karyawannya di masa yang hendak tiba. Pelatihan, pengembangan SDM serta perencanaan karir di PT. Pegadaian Gorontalo Utara diperuntukan guna mempertahankan serta meningkatkan prestasi kerja para karyawannya.

Sementara di Bali Star Academy, pelatihan pengembangan SDM berfokus terhadap pembentukan karakter jangka panjang, pembiasaan karakter Tuhan sebagai cerminan dan pedoman untuk menjalani hidup dalam situasi dan kondisi apapun, menghadapi tanggung jawab sedini mungkin dan meyakini bahwa diri anda berharga menjadi modal yang besar untuk perencanaan karir anak-anak BSA. Pelatihan Pembentukan Karakter BSA ditujukan untuk membentuk karakter positif.

Adapun hasil penelitian di BSA terdapat persamaan dan perbedaan dengan hasil penelitian oleh Ramli Mile, Peggy A. Mekel, Merlyn Karuntu. Adapun persamaannya yaitu pelatihan pembentukan SDM dilakukan untuk jangka panjang dimana khususnya di BSA adalah untuk membentuk karakter anak siap terjun ke dunia pekerjaan dengan etos kerja yang baik. Perbedaan yang paling mencolok adalah penelitian di BSA adalah penelitian yang dilakukan di sekolah yang bagaimana bisa disebutkan mereka adalah calon pekerja yang sedang dididik untuk siap masuk ke dalam dunia pekerjaan sedangkan penelitian pada PT. Pegadaian Gorontalo tentu sudah jelas merupakan penelitian yang dituju langsung untuk orang yang sudah bekerja di perusahaan tersebut.

Berdasarkan hasil penelitian dari Maunah dengan judul "Implementasi Pendidikan Karakter Dalam Pembentukan Kepribadian Holistik Siswa" (Maunah, 2016), menerangkan jika perihal awal terpaut pembentukan kepribadian anak bisa dicoba lewat 2 strategi, yakni internal sekolah serta eksternal sekolah. Kedua, strategi internal sekolah bisa dicoba lewat 4 pilar, yaitu aktivitas proses belajar mengajar di kelas, aktivitas keseharian dalam wujud budaya sekolah (school culture), aktivitas pembiasaan (habituation), aktivitas ko-kurikuler serta ekstra kurikuler. Ketiga, strategi eksternal bisa dicoba lewat keluarga serta warga. Keempat, kala segala strategi tersebut bisa dilaksana- kan dengan baik, hingga kepribadian anak hendak jadi tercipta serta kokoh.

Pada Bali Star Academy, melalui Devotion yang diikuti oleh siswa-siswi, guru, dan juga orang tua murid yang membuat semua pihak hingga orang tua murid mengetahui materi yang diberikan pada saat Devotion, membuat pembentukan karakter bisa dilakukan di lingkungan manapun dengan bantuan guru dan orang tua. 
Proses penyusunan kepribadian pada Bali Star Academy tidak hanya dicoba dalam penerapan Devotion, akan tetapi juga pada aktivitas belajar, keseharian di sekolah, aktivitas ekstra, serta seluruh tipe kegiatan dengan mengimplementasikan modul pembuatan kepribadian. Orang tua murid bisa berkolaborasi dengan guru buat menolong pembuatan kepribadian murid BSA di luar area sekolah, dikala di rumah atau pun dikala beraktivitas dengan keluarga. Terdapatnya kerjasama antara guru serta orang tua inilah yang membuat anak dapat terus melaksanakan pembiasaan menekuni kepribadian mana yang baik serta apa yang wajib dicoba, sehingga anak bisa terbiasa dengan karakter-karakter positif tersebut.

Penelitian ini mendukung penelitian yang dilakukan oleh Binti Maunah. Dimana strategi pembentukan karakter dari internal dan eksternal kampus merupakan hal penting dalam pembentukan karakter siswa. Perbedaan yang mencolok disini adalah BSA selain mengimplementasikannya pada internal dan eksternal sekolah yang melibatkan orang tua murid, namun murid juga diberikan tanggung jawab untuk sebagian besar acara-acara yang dibuat oleh BSA untuk langsung melatih dan menilai etos kerja yang dimiliki oleh anak-anak tersebut sejak dini.

Berdasarkan hasil wawancara dengan beberapa informan terpilih di Bali Star Academy maka untuk mengetahui perbandingan antara penelitian dari Hidayat dengan judul "Manajemen Sekolah Berbasis Karakter" (Hidayat, 2012), dimana dalam penelitian tersebut dapat disimpulkan bahwa Implementasi manajemen sekolah berbasis karakter, merupakan sebuah pendekatan yang sangat baik dalam upaya ketercapaian tujuan pendidikan nasional, secara filosofi, manajemen pendidikan berbasis karakter, merupakan kewajiban dan hakekat yang seharusnya terkondisikan sebagaimana filosofi dan tujuan pendidikan nasional yakni pembentukan peserta didik yang berwatak dan berakhlak.

Hal ini sejalan dengan Filosofi Devotion pada BSA, yaitu put God first, yang selaras dengan filosofi dan tujuan pendidikan nasional yakni pembentukan peserta didik yang berwatak dan berakhlak. Filosofi tersebut diyakini dapat mengefektifkan pembentukan karakter anak.
Dari pernyataan tersebut dapat disimpulkan bahwa adapun hasil penelitian di BSA mendukung penelitian oleh Asep Saepul Hidayat. Dimana sekolah berbasis karakter yang mengutamakan pembentukan karakter siswasiswinya merupakan pendekatan yang baik dalam upaya pencapaian tujuan pendidikan nasional.

\section{SIMPULAN}

Program pelatihan pembentukan karakter oleh BSA yaitu Devotion yang dilakukan setiap hari sebelum memulai kegiatan belajar mengajar diyakini sangat efektif dalam membentuk karakter siswa-siswi BSA. Dengan filosofinya put God first, dan do it for God and for others membuat etos kerja yang diberikan oleh lulusan BSA menjadi sangat baik. Mempelajari satu topik karakter selama sebulan penuh membuat proses pembiasaan berjalan dengan baik dan akan tertanam dalam diri mereka, hal yang dipelajari dalam Devotion akan dapat teringat sampai kapanpun karena telah terbiasa dan dapat diaplikasikan di kehidupan sehari-hari. Kerjasama antara guru dan juga orang tua murid menjadi kunci utama pembentukan karakter di BSA, orang tua murid juga diajak untuk mengikuti kegiatan Devotion ini dengan demikian implementasi dan pembiasaan pembentukan karakter dapat diperhatikan dari lingkungan sekolah dan juga lingkungan keluarga.

Lulusan BSA terlihat memiliki etos kerja yang sangat baik, dari pekerjaan yang dapat mereka selesaikan, dilihat dari tanggung jawab yang dipercayakan kepada mereka dari tempat mereka bekerja atau organisasi yang mereka tempati.

Menghadapi era disrupsi Devotion juga membentuk karakter yang harus dapat menerima perubahan dan mengikuti hal positif dari perubahan zaman tersebut, dan dalam penyampaian materi Devotion juga terus mengikuti perkembangan zaman khususnya teknologi, dalam acara-acara di BSA anak-anak diberikan tanggung jawab untuk menjadi panitia penyelenggara maupun pengisi acara untuk membiasakan mereka dengan suasana lingkungan pekerjaan dan bertanggung jawab menggunakan teknologi-teknologi tersebut. 


\section{DAFTAR RUJUKAN}

Adi, P. R. P., \& Indrawati, K. R. (2019). Perbedaan Keterikatan Kerja berdasarkan Generasi Kerja Karyawan pada Perusahaan Berkonsep THK ditinjau dari Etos Kerja. Jurnal Psikologi Udayana, 6(1), 46-57.

Amir Hamzah. (2016). Profil Pembelajaran Karakter Di Sekolah Dasar. 3(6), 31-50.

Budiono, K. (2007). Nilai-nilai Kepribadian dan Kejuangan Bangsa Indonesia. Alfabeta.

Campione, W. (2015). Corporate Offerings: Why Aren't Millennials Staying? The Journal of Applied Business and Economics, 17(4), 60-75.

Darby, V., \& Morrell, D. L. (2019). Generations at work: A review of generational traits and motivational practices impacting Millennial employees. Drake Management Review, 8(April 2019), 1-13.

Desmon, G. (2016). Etos Kerja; Panduan Menjadi Karyawan Cerdas. Elex Media Computindo.

Diamantidis, A. D., \& Chatzoglou, P. D. (2014). Employee post-training behaviour and performance: Evaluating the results of the training process. International Journal of Training and Development, 18(3), 149-170. https://doi.org/10.1111/ijtd.12034

Fitriani Lubis. (2019). Education in the Disruption Era. Britain International of Linguistics Arts and Education (BIoLAE) Journal, 1(2), 183188. https://doi.org/10.33258/biolae.v1i2.85

Ghufron, G. (2018). Revolusi Industri 4.0: Tantangan, Peluang, Dan Solusi Bagi Dunia Pendidikan. Seminar Nasional Dan Diskusi Panel Multidisiplin Hasil Penelitian Dan Pengabdian Kepada Masyarakat, 1(1), 332337.

Hidayat, A. S. (2012). Manajemen Sekolah Berbasis Karakter. Jurnal Inovasi Dan Kewirausahaan, 1(1), 8-22.

Hidayatullah, S., Waris, A., \& Devianti, R. C. (2018). Perilaku Generasi Milenial dalam Menggunakan Aplikasi Go-Food. Jurnal Manajemen Dan Kewirausahaan, 6(2), 240249. https://doi.org/10.26905/jmdk.v6i2.2560

Industri, R., Tantangan, D. A. N., \& Sosial, P. (2018). Revolusi Industri 4.0 Dan Tantangan Perubahan Sosial. IPTEK Journal of Proceedings Series, $0(5)$, $22-27$. https://doi.org/10.12962/j23546026.y2018i5.44 17

Karuntu, M., Mekel, P., \& Mile, R. (2014). Analisis Terhadap Pelatihan Dan Pengembangan Karyawan Bagi Peningkatan Kinerja Di Pt. Pegadaian Gorontalo Utara. Jurnal Riset
Ekonomi, Manajemen, Bisnis Dan Akuntansi, 2(4), 167-174. https://doi.org/10.35794/emba.v2i4.6235

LaCore, E. (2015). Supporting millennials in the workplace. Strategic HR Review, 14(4), 1-15. https://doi.org/10.1108/shr-06-2015-0046

Maemunah. (2018). Kebijakan pendidikan pada era revolusi industri 4.0. Prosiding Seminar Nasional Pengambdian 2018 Univeristas Muslim Nusantara Al-Washliyah, September, $1-8$.

Mathis, L. Robert \& Jackson, H. J. (2002). Manajemen Sumber Daya Manusia. Salemba Empat.

Maunah, B. (2016). Implementasi Pendidikan Karakter Dalam Pembentukan Kepribadian Holistik Siswa. Jurnal Pendidikan Karakter, 1, 90-101. https://doi.org/10.21831/jpk.v0i1.8615

Otieno, J. O., \& Nyambegera, S. M. (2019). Millennials and Generation Z Employees are here : Is your Organization ready? Journal of Language, Technology \& Entrepreneurship in Africa, 10(2), 68-85.

Risdianto, E. (2019). Analisis Pendidikan Indonesia di Era Revolusi Industri 4.0. Research Gate, April, 0-16.

Santoso, M. B., Nurwati, N., \& Apsari, C. N. (2019). Soft Skills As the Strength of Millenial Generation in the Age of Automation and Artificial Intelligence. 2008, 10-21.

Selwyn, N. (2013). Discourses of digital 'disruption' in education: a critical analysis. Fifth International Roundtable on Discourse Analysis, City University Hong Kong, May 2325, 2013, 1-28.

Sugiyono. (2010). Metode Penelitian Pendidikan Pendekatan Kuantitatif, kualitatif, dan R\&D. Alfabeta.

Sugiyono. (2017). Metode Penelitian Kombinasi. Alfabeta.

Syakdiyah, A., Nurmahmudah, F., \& Wijayanti, W. (2019). Active Learner Strategies in Era of Disruption: a Literature Review. 317(IConProCS), 165-168. https://doi.org/10.2991/iconprocs-19.2019.34

Syamsuddin. (2020). Model Kolaboratif Bimbingan Karir Universitas Malikussaleh Dalam Meningkatkan. Jurnal Ilmu Administrasi Bisnis, 3(2), 176-188.

Wijanarko, R. (2019). Revolusi Industri keempat, Perubahan Sosial dan Strategi Kebudayaan, Robertus. Siapakah Manusia; Siapakah Allah Menyingkap Tabir Manusia Dalam Revolusi Industri Era 4.0, 101-116. 